including, for example, a model of the calorimeter building at the Fuel Research Station and photographs illustrating the work of the Shirley Institute. The exhibition is admirably designed to achieve its purpose of demonstrating the value of technical information to industry in general.

\section{Exhibition of Spanish Scientific Books}

Av exhjbition of recent Spanish publications in science, technology and medicine, organized by the Institute of Spain, was opened by Mr. K. B. Potter, president of the Publishers' Association, in the Science Museum Library, on November 6 . In welcoming the exhibition Dr. F. Sherwood Taylor, director of the Science Museum, recalled the evidence in Spain of the enormous antiquity of Spanish metallurgy and acclaimed the Spaniard as a great practical chemist and engineer. He looked back to the age of Alfonso the Wise, when Spanish astronomers led the world, to Ramin Lull, who founded a school important in the progress of chemistry, and to the debt owed to Spain for the development of the merino breed of sheep, founders of great flocks in three continents. This exhibition, he added, demonstrated the vigorous life of science in Spain to-day, particularly in the fields of medicine and engineering. His Excellency the Spanish Ambassador, in closing the ceremony, mentioned that the exhibition contains only a sample of the scientific books, particularly original treatises, published in Spain during the past few years-a period in which scientific activity has been intensified with the development of collective efforts in research and teaching as Spain has become increasingly industrialized. $\mathrm{He}$ also referred to the wide circulation of both standard textbooks and original works through Spain and Spanish America. In expressing his gratitude to the Science Museum for opening its library to the exhibition, he spoke of the universal interest in science, of the admiration in Spain for the scientific culture of Great Britain and of the world of science which speaks of friendship and a common task. The exhibition will remain open until November 20.

\section{Quantitative Paper Chromatography of Plant Nitrogen}

THE value of quantitative partition ehromatography on paper in the analysis of the alcoholinsoluble nitrogen of plants has been established in recent investigations by J. F. Thompson and F. C. Steward (J. Exp. Bot., 3, No. 8, 170; 1952). The amino-acid composition of egg albumin, zein, edestin and cucumber seed globulin has been determined by a quantitative method which is described, the chromatographic analytical data accounting completely for the amino-acid nitrogen of the protein hydrolysate as determined by the Kjeldahl method. The analyses of the alcohol-soluble and -insoluble fractions of potato tubers of several varieties have now been carried out, attention being directed to differences which have been observed as between both samples and varieties. No correlation has been observed between the relative proportions of free amino-acids in the tubers and in the alcohol-insoluble protein; indeed, certain compounds present in the free state in the tissue do not occur in the protein, while the amides are stated to be considerably in excess of their possible occurrence combined in the protein. Hence the tentative conclusion is reached that the free soluble compounds are not directly combined as such to form proteins.

\section{Petrological Identification of Stone Axes}

THE third report of the Committee concerned with the petrological identification of stone axes is published in the Proceedings of the Prehistoric Society for 1951 (Pt. 2). Polished celts are frequently made from fine-grained igneous rocks, tough materials making carpentry possible. In thin sections these rocks can be identified under a polariscope, and sometimes the material is not one of common occurrence. In such cases the site whence came the rock substance can be located, and indeed a number of such workshop sites are known. This third report continues the investigations and gives much more information on this interesting matter which helps to suggest the lines of ancient trade routes along which were passed the raw materials utilized for the making of ground and polished celts.

\section{Reopening of the Mining Collection at the Science Museum, London}

ThE Mining Collection at the Science Museum, South Kensington, London, S.W.7, will be reopened in much enlarged form by the Right Hon. Geoffrey Lloyd, Minister of Fuel and Power, on November 18. The basic conception in the design of the new Collection, which occupies an area of nine thousand square feet, has been to give the visitor the impression of being underground in the actual workings of a mine; one of the principal exhibits is a full-scale model of a coal face supplied with the latest equipment and machinery. Adjacent to this are various sections illustrating the historical development of the many ancillary services which are essential in mining and which have played such an important part in the safety and social progress of the miner; these sections deal with coal-cutting, metalliferrous mining, breaking ground, mine transport, winding, boring and sinking, mine lighting, mine ventilation, rescue work, hand tools, roof supports and surface mining. The development and building of this Collection has only been made possible by the kindness and generosity of the many manufacturers of mining equipment used in Great Britain, who have provided not only full-sized equipment but also many fine models and finance.

\section{Insignia Award of the City and Guilds of London Institute}

ThE City and Guilds of London Institute has recently established an "Insignia Award" in technology which is designed to be a mark of distinction conferred by the Institute on those who have combined with a sound practical training an adequate knowledge of the fundamental scientific principles of their industry and have shown a capacity for leadership and administration and for applying such wider knowledge to their particular industry. The Award will entitle the holder to use the letters C.G.I.A. after his name. The five main sections at present approved for the Award are the chemical, constructional, electrical, mechanical and textile industries; but these divisions are meant to cover a broad range of particular industries. The preliminary conditions required of a candidate are that he be not less than thirty years of age, have completed the full period of apprenticeship or equivalent training suitable for his industry, have obtained the Full Technological Certificate of the Institute in an appropriate branch of technology, have had at least seven years suitable industrial experience subsequent to his initial apprenticeship 